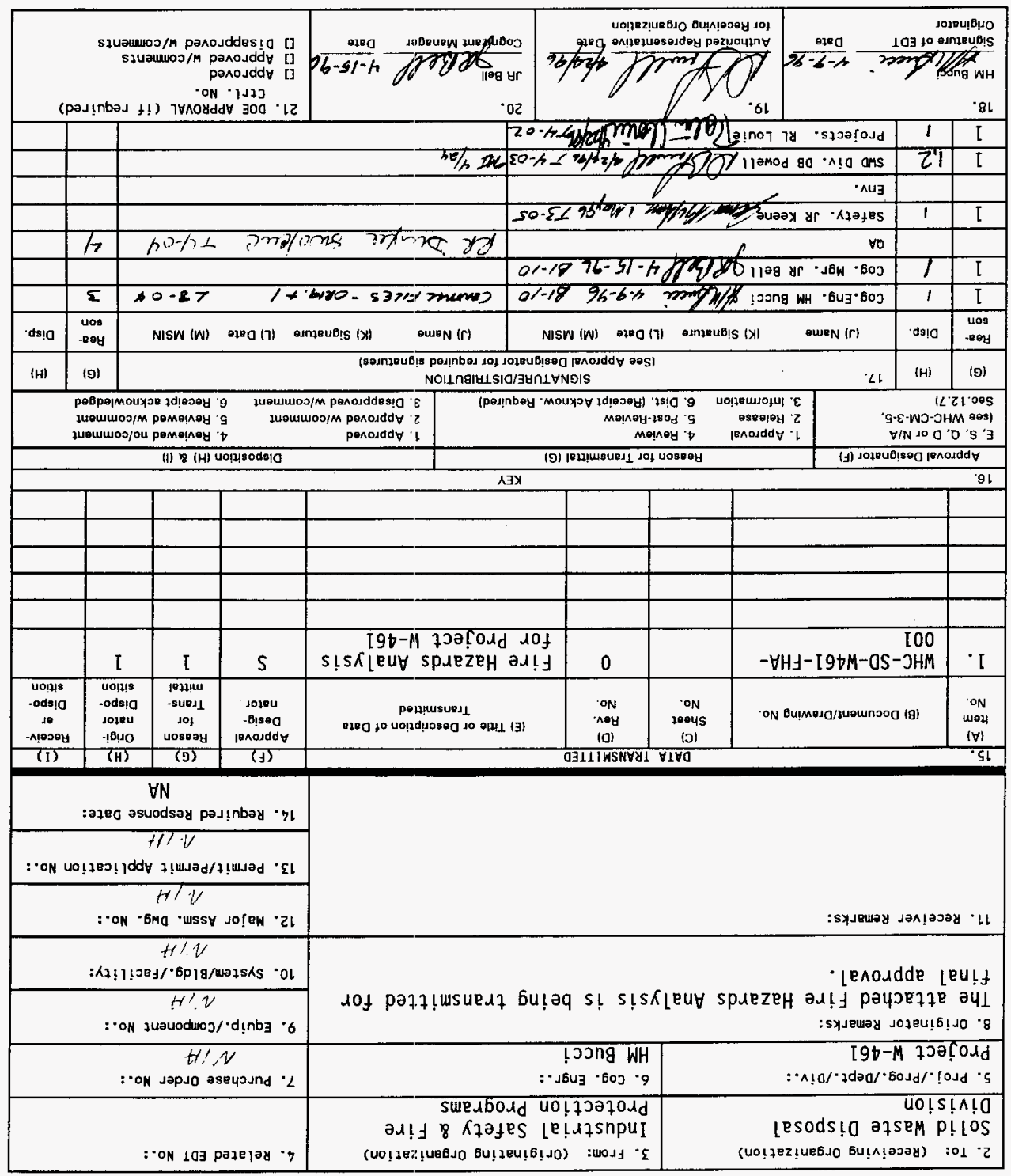




\title{
FIRE HAZARDS ANALYSIS FOR PROJECT W-461
}

\author{
HM Bucci \\ Westinghouse Hanford Company, Richland, WA 99352 \\ U.S. Department of Energy Contract DE-ACOGi-87RL10930

$\begin{array}{lll}\text { EDT/ECN: } & 140025 & \text { UC: } 620 \\ \text { Org Code: } & 31 \mathrm{CO0} & \text { Charge Code: } \\ \text { B\&R Code: } & 39 E W 31302 & \text { Total Pages: } 18\end{array}$

Key Words: Fire Hazards Analysis, Project: W-461

Abstract: A graded fire hazards analysis was performed in accordance with the Solid Waste Disposal Standards/Requirements Identifications Document (SRID), to confirm compliance with the SRID.

TRADEMARK DISCLAIMER. Reference herein to any specific ccmercial product, process, or service by trade name, trademark, manufacturer, or otherwise, does not necessarily constitute or imply its endorsenent, recommendation, or favoring by the United States Government or any agency thereof or its contractors or subcontractors.

Printed in the United States of America. To obtain copies of this docunent, contact: WHC/BCS Document Control Services, P.O. Box 1970, Mailstop H6-08, Richland WA 99352, Phone (509) 372-2420; Fax (509) 376-4989.
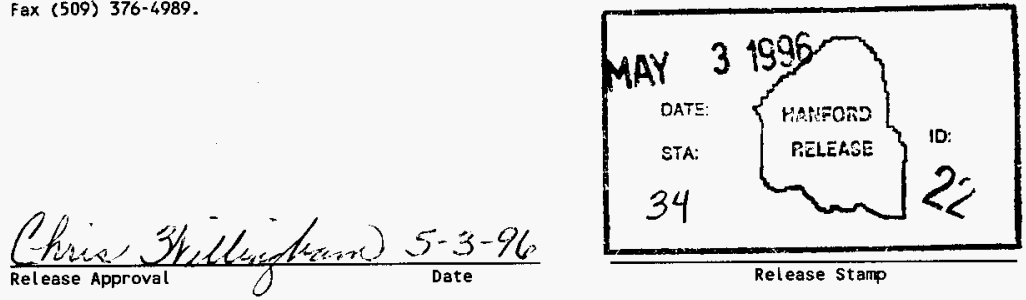

Release stanp 


\title{
FIRE HAZARDS ANALYSIS
}

\section{FOR}

\section{PROJECT W-461}

WHC-SD-W461-FHA-001, Rev. 0

\author{
Westinghouse Hanford Company \\ Apri1 1996 \\ Prepared by \\ H. M. Bucci \\ Fire Protection Programs
}


TABLE OF CONTENTS

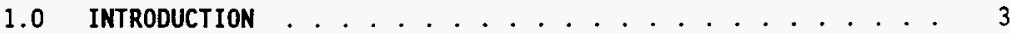

2.0 SUMMARY AND CONCLUSIONS ................... 4

3.0 DESCRIPTION OF CONSTRUCTION . . . . . . . . . . . . . . . . . 4

4.0 FIRE PROTECTION FEATURES . . . . . . . . . . . . . . . . . . 4

5.0 DESCRIPTION OF FIRE HAZARDS . . . . . . . . . . . . . . . . 5

6.0 PROTECTION OF ESSENTIAL SAFETY CLASS SYSTEMS . . . . . . . . 6

7.0 LIFE SAFETY CONSIDERATIONS . . . . . . . . . . . . . . . . . . 6

8.0 CRITICAL PROCESS EQUIPMENT . . . . . . . . . . . . . . . . 6

9.0 HIGH VALUE PROPERTY . . . . . . . . . . . . . . . . . 6

10.0 DAMAGE POTENTIAL _. . . . . . . . . . . . . . . 6

10.1 MAXIMUM CREDIBLE FIRE LOSS (MCFL) . . . . . . . . . . . 6

10.2 MAXIMUM FORESEEABLE FIRE LOSS (MFFL) . . . . . . . . . . 7

11.0 FIRE DEPARTMENT/BRIGADE RESPONSE . . . . . . . . . . . . . . 7

12.0 RECOVERY POTENTIAL . . . . . . . . . . . . . . . . 7

13.0 POTENTIAL FOR A TOXICOLOGICAL, BIOLOGICAL, AND/OR

14.0 EMERGENCY PLANNING . . . . . . . . . . . . . . . . . . . . . . . 8

15.0 SECURITY AND SAFEGUARDS CONSIDERATIONS RELATED TO FIRE

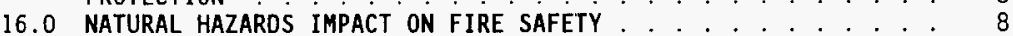

16.1 FLOODS . . . . . . . . . . . . . . . . 8

16.2 TORNADOES . . . . . . . . . . . . . . . . . . . 8

16.3 EARTHQUAKES . . . . . . . . . . . . . . . 9

17.0 EXPOSURE FIRE POTENTIAL . . . . . . . . . . . . . . . . . . . 9

18.0 RECOMMENDATIONS . . . . . . . . . . . . . . . . . . . 9

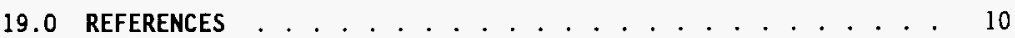

20.0 APPENDIXES -A Content Values ............... 11

-B Property Loss Estimate . . . . . . . . . . . . 13

-C Ceiling Jet Plume................ 14

-D Drawings . . . . . . . . . . . . . . 16

Page 1 of 16 


\section{ACRONYMS}

$\begin{array}{ll}\text { ASTM } & \text { American Society for Testing \& Materials } \\ \text { BED } & \text { Building Emergency Director } \\ \text { BTU } & \text { British Thermal Unit } \\ \text { DOE } & \text { U. S. Department of Energy } \\ \text { FHA } & \text { Fire Hazards Analysis } \\ \text { GPM } & \text { Gallons per Minute } \\ \text { KPA } & \text { Kilopascals } \\ \text { L/MIN } & \text { Liters/minute } \\ \text { MCFL } & \text { Maximum Credible Fire Loss } \\ \text { MFFL } & \text { Maximum Foreseeable Fire Loss } \\ \text { NFPA } & \text { National Fire Protection Association } \\ \text { PSI } & \text { Pounds per Square Inch } \\ \text { SFPE } & \text { Society of Fire Protection Engineers }\end{array}$




\subsection{INTRODUCTION}

A FHA is required for new facilities per Section 12.4 of the Solid Waste Disposal Division "Standards/Requirements \& Identifications Document" (SRID), Rev.4 (WHC-IP-1120). The Project consists of two, $18 \mathrm{~m} \times 27 \mathrm{~m}$ ( 60 $\mathrm{ft} . \times 90 \mathrm{ft}$. ) framed fabric structures which will be used to store equipment, vehicles, trailers, manlifts, drums, etc., in support of the Central Waste Complex (CWC) activities.

In light of the proposed occupancy, Tower dollar value, and the facilities being non-nuclear structures, a "graded" fire hazards analysis was performed. The analys is evalluates the potential fire risks to determine if any undue hazards require mitigation to protect employees, property, the public, or the environment. The specific objectives include the following:

1. Minimize the potential for the occurrence of a fire or related perils.

2. Ensure that fire does not cause an unacceptable onsite or offsite release of hazardous material that will threaten the public health and safety, or the environment.

3. Establish requirements consistent with the National Fire Protection Association 101 Life Safety Code that will provide an acceptable degree of life safety to DOE and contractor personnel, and that there are no undue hazards to the public from fire and its effects in DOE facilities.

4. Ensure that vital DOE programs will not suffer unacceptable delays (defined by the program senior official) as a result of fire and related perils.

5. Ensure that property damage from fire and related perils does not exceed DOE established levels.

6. Ensure that process control and safety systems are not damaged by fire or related perils. 


\subsection{SUMMARY AND CONCLUSIONS}

Two sprung structures covered with a fire retardant fabric will be erected for the storage of equipment to support the CWC operations. The structures will essentially serve as a covered lay-down yard to protect equipment from the weather. This Fire Hazards Analysis (FHA) was prepared following the Solid Waste Disposal Division (SWDD) SRID, Rev.4 (WHC-IP-1120). The FHA did not identify the need for automatic fire suppression, based on the storage planned for these facilities as identified by 0perations. In an effort to ensure the equipment stored in the structures is maintained consistent with the basis of this FHA, a formal documented procedure, or equivalent means, should be developed to control the type and quantity of storage. This is considered a "best management" practice to ensure compliance with the SWDD SRID is maintained, and to preclude the need for automatic sprinkler protection.

This FHA is based on the type of storage identified in Appendix $A$ and similar pieces of equipment. The storage of items such as radioactive materials, hazardous/ignitable materials (outside the exempt amounts permitted by the UBC/UFC), and wood pallets, are not within the scope of this FHA. Introducing these types of materials will undoubtedly increase the ability of a fire to propagate, resulting in a dollar loss that could exceed the limitations of the SWDD SRID.

\subsection{DESCRIPTION OF CONSTRUCTION}

Two structures $18 \mathrm{~m} \times 27 \mathrm{~m}(60 \mathrm{ft} . \times 90 \mathrm{ft}$.) will be erected to satisfy the structural requirements of a Type $V$, nonrated facility per the Uniform Building Code (UBC). Due to the sloping sides, the structures useable space will be between $427-446 \mathrm{~m}^{2}\left(4,600-4,800 \mathrm{ft}^{2}\right)$. The two structures will be fabricated of noncombustible structural components, overlaid with a fire retardant fabric membrane. They will be positioned on a concrete or asphalt foundation and provided with three personnel and one cargo access door. Interior lighting will be provided by skylights and ventilation will be provided by natural convection. There are no other utilities planned for the structures. The UBC occupancy classification will be Group 5, Division 3 .

\subsection{FIRE PROTECTION FEATURES}

The fabric membrane will be fire retardant and comply with the Uniform Building Code (UBC) Standard 31-1, "Flame Retardant Membranes" or the National Fire Protection Association (NFPA) 701, "Standard Methods of Fire Tests for Flame-Resistant Textiles and Films". Fire hydrants will be provided per Section 903 of the Uniform Fire Code (UFC). At least one hydrant having a flow capacity of $6,624 \mathrm{~L} / \mathrm{min}$. (1,750 gpm) will be provided within 76 meters (250 ft.) of the structures. Portable fire extinguishers will also be provided per Section 3209 of the UFC. 
The water supply to the CWC is provided via the 200 West area sanitary water system. The $283 \mathrm{~W}$ Water Treatment $\mathrm{Plant}$ has a maximum rated flow of $12,108 \mathrm{~L} / \mathrm{min}(3,200 \mathrm{gal} / \mathrm{min})$. Filtered and treated water flows from the treatment plant to clearwelis for storage. There are two clearwells with a total storage capacity of $1,514,160 \mathrm{~L}(400,000 \mathrm{ga} 1)$ of sanitary water. The current pumping capacities from the clearwells to the sanitary water distribution piping are summarized below.

- 200 West

Four, 3,785 L/min (1,000 gal/min) electric pumps

One, $3,785 \mathrm{~L} / \mathrm{min}(3,500 \mathrm{gal} / \mathrm{min})$ steam pump

Two, 2,27l L/min (600 gal/min) steam pumps

Flow tests were performed at the CWC in March 1995 and a summary of the test results are provided below.

Hydrant flowed - 3WF

Hydrant press. - 9WF

Static: $800 \mathrm{kPa}(116 \mathrm{psi})$

Residual: 441 - $620.5 \mathrm{kPa}(64-90 \mathrm{psi}$, second pump came online)

Flow: $4200-46201 / \mathrm{min}$. (112l - $1219 \mathrm{gpm}$, second pump came online)

\subsection{DESCRIPTION OF FIRE HAZARDS}

The primary fire hazards will be associated with the contents stored in the structures. These may include propane powered fork 7 ifts and scissor lifts, snow plows and blowers, pallets of absorbent and de-icer, and vehicles, etc. The fabric membrane is not considered a fire hazard in itself.

In 1994 Factory Mutual Research Corporation performed a full-scale fire test of a tension supported membrane structure and found that the fire retardant fabric $\left(28 \mathrm{oz} . / \mathrm{yd}^{2}\right)$ would not self-propagate. The fabric burned only to the extent that it was exposed to the flames of the test fire. The strength of the steel support structure was also maintained throughout the duration of the fire test.

The fabric being proposed for these structures is "Vernotex" (18 $\left.0 z . / \mathrm{yd}^{2}\right)$. It has been tested and meets the flame retardant tests of NFPA 701 for small and large scale specimens. The fabric was also tested and passed the UBC Standard 55-1, "Flame Retardant Membranes" 
(1991 edition), and Underwriters Laboratories (UL) Standard UL-214, "Test for Flame Propagation of Fabrics \& Films". When tested in accordance with ASTM E-84-89a, the fabric received a flame spread of 10 and a smoke developed value of 240 . The fabric meets the interior finish requirements of the UBC. The support structure will be aluminum.

\subsection{PROTECTION OF ESSENTIAL SAFETY CLASS SYSTEMS}

There are no essential safety class systems related to these structures. Consequently, there is no need for special fire protection for safety class systems.

\subsection{LIFE SAFETY CONSIDERATIONS}

The structures will meet the egress requirements outlined in Chapter 10 , "Means of Egress" of the UBC, and Article 32, Section 3211 of the UFC. There will be a minimum of 3 personnel exits arranged so the maximum travel distance does not exceed $30 \mathrm{~m}$ (100 feet). Self-illuminating, nonelectrical exit signs will be provided above each exit door per Section 3214 of the UFC.

\subsection{CRITICAL PROCESS EQUIPMENT}

There is no critical process equipment required for these structures, or stored within them.

\subsection{HIGH VALUE PROPERTY}

Fire protection of high value property: There is no high value property in the facility that warrants additional fire protection features.

\subsection{DAMAGE POTENTIAL:}

The loss potential for Solid Waste Facilities is based on their Standards Requirements \& Identifications Document (SRID). Automatic fire suppression is required as follows: In all structures having a Maximum Foreseeable Loss (MFL) as defined in Factory Mutual (FM) System Loss Prevention Data Section 1.22 Paragraph 5.1\} in excess of $\$ 1,000,000$ or where the maximum credible fire will result in the loss of use of a vital structure for a period longer than that specified as acceptable by the applicable PSO.

\subsection{MAXIMUM CREDIBLE FIRE LOSS (MCFL)}

The scenarios for the MCFL and the MFL would be considered the same due to the absence of an automatic fire suppression system. The most credible event would probably involve a propane leak from one of the propane powered pieces of equipment and subsequent ignition. Due to the 
size of the structure, the open volume of space. and the type of items planned for storage, the fire would not be expected to propagate beyond one or two adjacent pieces of equipment. FPE TOOL was used to postulate the ceiling temperatures and yielded results that could exceed the melting point of the fabric (see Appendix $C$ ). If temperatures at the ceiling reach the melting point $\left(320^{\circ} \mathrm{F}\right)$, the most significant consequence would be a natural venting of the heat through the fabric, if the turbo ceiling vents were not adequate to release the buildup. Isolated damage to the aluminum support structure would also be expected.

The most expensive pieces of equipment identified by Operations (see Appendix A) were a tractor valued at $\$ 396 \mathrm{~K}$, and two aerial 1 ifts valued at $\$ 55 \mathrm{~K}$ and $\$ 52 \mathrm{~K}$. Assuming the fire involved these pieces of equipment, a maximum loss of $\$ 580 \mathrm{~K}$ is postulated (see Appendix B).

David Morse at Vernon Plastics Company said (via a telecon with HM Bucci on 4-1-96) the melting point of the material was about $320 \stackrel{\circ}{\circ}$, and the material consisted of a polyester fabric laminated on both sides with fire retardant treated polyvinylchloride.

\subsection{MAXIMUM FORESEEABLE FIRE LOSS (MFFL)}

The MFFL per FM would be the same as the MCFL postulated above.

\subsection{FIRE DEPARTMENT/BRIGADE RESPONSE}

(a) Fire Department apparatus accessibility: Each structure is provided with a $6 \mathrm{~m}$ (20 foot) access road, and the areas around the structures are clear and unobstructed. Paved roads are planned on two sides of the structures. Fire department apparatus can gain access to the structures for fire al arm response.

(b) Fire Hydrants: Fire hydrants were equipped with substantial bollards to prevent vehicular damage. The arrangement of parking and roadways is designed to enhance accessibility. There will be at least one hydrant within $76 \mathrm{~m}(250 \mathrm{ft})$ of the structures per the UFC. The nearest hydrant is located West of Building 2402-W.

(c) Prefire Plan: The Hanford Fire Department must develop a pre-fire plan or address the addition of the structures in the pre-fire plans for the other structures currently present at the Central Waste Complex (CWC).

\subsection{RECOVERY POTENTIAL}

None of the equipment planned for storage in these structures is vital to the CWC operations, or considered unique in that a long lead time 
would be experienced for replacement. It is expected that the loss of any given piece of equipment due to fire could be replaced within a month or less, subject to funding availability.

\subsection{POTENTIAL FOR A TOXICOLOGICAL, BIOLOGICAL, AND/OR RADIOLOGICAL INCIDENT DUE TO A FIRE}

These structures are non-nuclear, non-radiological, and the contents will not be radiologically contaminated. Consequently, there is no potential for a radiological release due to a fire at these structures. The only releases postulated are the products of combustion that are normally emitted from a fire involving ordinary type combustibles (paper, cloth, plastic, etc.) or possibly flammable/combustible liquids/gases used to power the motor vehicles.

\subsection{EMERGENCY PLANNING}

There are no special emergency procedures for these facilities beyond those normally required and implemented when responding to a fire or other emergency alarm. Any special considerations should be addressed in the pre-fire plan covering these structures.

\subsection{SECURITY AND SAFEGUARDS CONSIDERATIONS RELATED TO FIRE PROTECTION}

Vehicle access to the facilities is free and unobstructed, and the building is normally unoccupied. There are no special security requirements for these facilities that would impact, or otherwise adversely affect fire protection efforts.

\subsection{NATURAL HAZARDS IMPACT ON FIRE SAFETY}

\subsection{FLOODS}

The U.S. Army Corps of Engineers projected a dam-regulated probable maximum flood using extensive data and computer modeling, and incorporating assumptions considered reasonably possible for the Columbia River Basin. Contributing factors of winter snow accumulation, spring melt-off, and seasonal rainstorms were maximized. Under these conditions, there would be no impact to the 200 Areas operations from a flood. This FHA also concludes that there would be no adverse impact on fire protection at the sprung structures.

\subsection{TORNADOES}

The Pacific Northwest is an area of the country with the lowest frequency of tornadoes. Washington State has an average tornado frequency of less than one per year. An analysis of the Hanford Site 
concluded that the chances of a tornado hitting a given facility on the site is six chances in a million during any one year.

Based on the data provided by Babowal Builders \& Engineers LTD, the structures having a height of $18 \mathrm{~m}$ ( 60 feet) can withstand wind velocities up to $196 \mathrm{~km} / \mathrm{hr}$ (122 mph). This FHA concludes that there would be no adverse impact on fire protection at the sprung structures due to a tornado.

\subsection{EARTHQUAKES}

The Hanford Site is exposed to the possibility of a moderate earthquake (zone 2) from active seismic zones in western Washington and southeast Washington near Walla Walla. This FHA did not identify any incidents that would impact fire protection at the sprung structures due to an earthquake.

\subsection{EXPOSURE FIRE POTENTIAL}

In accordance with UBC, Table 5-A, the structures must be separated from each other and from other exposures, by at least $12 \mathrm{~m}(40 \mathrm{ft})$. The UFC, Section 3219.2, requires areas adjacent to or within $9 \mathrm{~m}(30 \mathrm{ft}$ ) of the structures to be clear of vegetation. These distances will be met. There were no potential exposure hazards identified that would warrant additional fire protection measures considering the above requirements.

\subsection{RECOMMENDATIONS}

RECOMMENDATION $W-461-96-1$ :

In an effort to ensure the equipment stored in the structures is maintained consistent with the basis of this FHA, a formal documented procedure, or equivalent means, should be developed to control the type and quantity of storage. The procedure should be developed under consultation with the Solid/Liquid Waste Safety fire protection pointof-contact. This is considered a "best management" practice to ensure compliance with the SWDD SRID is maintained, and to preclude the need for automatic sprinkler protection. 


\subsection{REFERENCES}

Landrock, A.H., 1983, Handbook of Plastics Flammability and Combustion Toxicology, Noyes Publications, Park Ridge, NJ.

Meidl, J.H., 1978, Flammable Hazardous Materials, Second Edition, Glencoe Publishing Co., Encino, CA.

NFPA 1990a, Industrial Fire Hazards Handbook, Third Edition, National Fire Protection Association, Quincy, MA.

NFPA 1991, Fire Protection Handbook, Seventeenth Edition, National Fire Protection Association, Quincy, MA.

NFPA 1994a, Hazardous Chemical Data, NFPA 49, National Fire Protection Association, Quincy, MA.

Perry's, 1984, Chemical Engineers Handbook, Sixth Edition, McGraw-Hill.

SFPE/NFPA 1988, The SFPE Handbook of Fire Protection Engineering, Society of Fire Protection Engineers, Boston, MA and National Fire Protection Association, Quincy, MA.

WHC-SD-CP-FHA-002, 1995, FHA for T Plant Complex

WHC-IP-1120, Rev.4, "Standards/Requirements \& Identifications Document", Solid Waste Disposal Division 


\section{APPENDIX A}

Subject: Equipment

Author: Rhonda R Durfee at "WHC228

Date: $\quad 3 / 25 / 963: 17 \mathrm{PM}$

Pat,

Projects are working on placing sprung structures at CWC for equipment storage use. They have asked for a list of items that will be stored in these modules and a estimated cost of each item. Do you have approximate costs for the following or know where I might get them?

Forklifts

Scissor $l$ ifts

Aerial lifts

Cushmans

Electric carts

Any help would be greatly appreciated.

Thanks, Rhonda

Rhonda,

Below is the approx. value of the equipment I felt had the POTENTIAL to be stored in the new structure. At best, the 1 ist is just a good start you can add or subtract items from. Values are in thousands of dollars using the depreciated or estimated current value. If I can be of further help let me know.

Pat

$\mathrm{HO}-62-4204$

$\mathrm{HO}-62-5238$

$\mathrm{HO}-1 \mathrm{E}-132$

HO- $\mathrm{E}-133$

$\mathrm{HO}-1 \mathrm{E}-486$

HO- $1 E-500$

HO- 06-3730

HO-34-3906

HO-34-3908
Ford tractor Honda tractor Cushman scooter Cushman scooter Taylor-Dunn scooter Nordscog scooter Sweeper Simon scissor lift Simon aerial lift

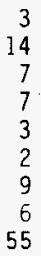

Page 11 of 16 


\section{APPENDIX A cont'd}

\begin{tabular}{|c|c|c|}
\hline $\begin{array}{l}\mathrm{HO}-34-3910 \\
\mathrm{HO}-34-3912 \\
\mathrm{HO}-62-5509 \\
\mathrm{HO}-74-4982 \\
\mathrm{HO}-74-4983 \\
\mathrm{HO}-74-5103 \\
\mathrm{HO}-74-5104 \\
\mathrm{HO}-74-5816 \\
\mathrm{HO}-74-5872 \\
\mathrm{HO}-75-3924 \\
\mathrm{HO}-75-4671 \\
\mathrm{HO}-75-4677 \\
\mathrm{HO}-75-4699 \\
\mathrm{HO}-75-4994 \\
\mathrm{HO}-75-4995 \\
\mathrm{HO}-78-5750 \\
\mathrm{HO}-78-6045\end{array}$ & $\begin{array}{l}\text { Simon scissor lift } \\
\text { Grove aerial lift } \\
\text { John Deere tractor } \\
\text { Sampling trailer for TRU } \\
\text { Sampling trailer for TRU } \\
\text { Amida light plant } \\
\text { Amida light plant } \\
\text { Lima generator } \\
\text { Onan generator } \\
\text { Clark forktruck } \\
\text { Clark forktruck } \\
\text { Clark forktruck } \\
\text { TCM forktruck } \\
\text { Clark forktruck } \\
\text { Clark forktruck } \\
\text { Spray rig } \\
\text { Spray rig } \\
\text { Snow blowers ( } 5 \text { each ) total value } \\
\text { Misc. Small tools, handtrucks, etc } \\
\text { Forktruck attachments/Hoisting equip. } \\
\text { Hydraulic table, air chiller }\end{array}$ & $\begin{array}{r}9 \\
52 \\
396 \\
35 \\
35 \\
12 \\
12 \\
1 \\
3 \\
23 \\
20 \\
18 \\
27 \\
26 \\
26 \\
2 \\
10 \\
13 \\
4 \\
12 \\
6\end{array}$ \\
\hline & & 848 \\
\hline
\end{tabular}




\section{MAXIMUM FORESEEABLE FIRE LOSS ESTIMATE}

Equipment Damage $\$ 503,000$

Structure Damage $\quad 40,000$

Cleanup " $\quad 37,000$

Tota $1 \$ 580,000$

- Damage to the structure was estimated based on the total purchase price for the units of $\$ 75 \mathrm{~K}$ each. The loss assumes the ceiling temperature reaches a level to cause the fabric membrane to melt, and causes isolated damage to the aluminum support structure, requiring replacement in part.

" The cleanup costs are an estimate to remove and dispose of the damaged equipment and any residual debris. 


\section{APPENDIX C}

The following analysis was performed using FPE TOOL V3.2, to estimate the ceiling jet temperature from a fire involving ignition of a propane powered piece of equipment. The explanation below is provided by FPE TOOL for this particular program.

"Ceiling plume jet temperature inside plume impingement zone, applies at points on the ceiling that are directly over the center of the fire source or not over about 0.2 times the height of the plume away from that point. The calculated temperature is conservative on the high side. It is recommended that this computation be used when estimating the damaging impact of ceiling jets. These values are not recommended when estimating ceiling jet temperatures to predict device actuation time.

Unless the room or space involved has ceiling vents to remove the hot gases that accumulate at the ceiling, a hot gas layer will eventually build up sufficiently to cause the temperature to rise above that predicted by this procedure. The procedure reports the approximate time when this rise starts."

The following parameters were determined for the input data:

No nearby walls were considered since the fabric membrane would not serve as a wall barrier (if the fire originated adjacent to the wall of the structure, a burn through would result and the heat would be emitted to the outside.)

The distance from the fuel to the ceiling was set at $6 \mathrm{~m}(20 \mathrm{ft})$ since the structures have a ceiling height of $8 \mathrm{~m}(26 \mathrm{ft})$. The ceiling area was determined to be $167 \mathrm{~m}^{2}\left(1800 \mathrm{ft}^{2}\right)$. This was calculated using the total length of the structure and $1 / 3$ of the total width to compensate for the sloped walls up to the ceiling peak.

The radiant distance from the fire axis was assumed at $3 \mathrm{~m}(10 \mathrm{ft})$, and the ambient temperature was set at $85^{\circ} \mathrm{F}$. The burn rate was conservatively estimated at $2667 \mathrm{~kW}$.

Under these parameters, the procedure predicts a jet of hot gas of $463^{\circ} \mathrm{F}$. The temperature would be expected to rise above this figure in about 1 minute if ceiling vents were not present to release the heat. The structures will have two, $51 \mathrm{~cm}$ (20 in.) turbo roof vents.

The burn rate was determined based on the following:

Propane yields $50.35 \mathrm{MJ} / \mathrm{kg}(21,684 \mathrm{BTU} / 1 \mathrm{~b})$ per NFPA Handbook, 17th Edition, Table A-1. 
Based on a $16 \mathrm{~kg}$ (35 1b) cylinder, a total heat release of $806 \mathrm{MJ}$ is available. Considering a 5 minute period (assumed for the scenario) for the propane to be expelled from the cylinder, $161 \mathrm{MJ} / \mathrm{min}(151,788$ $\mathrm{BTU} / \mathrm{min}$ ) would burn.

$151,788 \mathrm{BTU} / \mathrm{min} \times 0.01757=2667 \mathrm{~kW}$ 
WHC-SD-W461-FHA-O01, Rev.O

Project W-461

APPENDIX D

Page 16 of 16 